\title{
Study of the effect of four warm mix asphalt additives on bitumen modified with $15 \%$ crumb rubber
}

\author{
Ana María Rodríguez-Alloza ${ }^{\mathrm{a}, *}$, Juan Gallego ${ }^{\mathrm{a}}$, Ignacio Pérez ${ }^{\mathrm{b}}$
}

\begin{abstract}
A B S T R A C T
Due to a growing concern over global warming, the bituminous mixture industry is making a constant effort to diminish its emissions by reducing manufacturing and installation temperatures without compromising the mechanical properties of the bituminous mixtures. The use of mixtures with tyre rubber has demonstrated that these mixtures can be economical and ecological and that they improve the behaviour of the pavements. However, bituminous mixtures with a high rubber content present one major drawback: they require higher mixing and installation temperatures due to the elevated viscosity caused by the high rubber content and thus they produce larger amounts of greenhouse gas emissions than conventional bituminous mixtures.

This article presents a study of the effect of four viscosity-reducing additives (Sasobit ${ }^{\circledR}$, Asphaltan $A^{\text {B }}$ Asphaltan $B^{6}$ and Licomont BS $100^{6}$ ) on a bitumen modified with $15 \%$ rubber. The results of this study indicate that these additives successfully reduce viscosity, increase the softening temperature and reduce penetration. However, they do not have a clear effect on the test for elastic recovery and ductility at $25^{\circ} \mathrm{C}$.
\end{abstract}

\section{Introduction}

In recent years, environmental protection, energy savings and sustainable development have become important global themes. In road construction, new technologies such as warm-mix asphalt (WMA) and mixes with crumb rubber have been actively developed to promote energy savings and protect the environment.

Crumb rubber has been being used as an environmentallyfriendly material which produces pavements with good mechanical behaviour, reduces the noise caused by traffic as well as road maintenance costs, while increasing the life of the pavement [1-4].

However, the manufacture of asphalt rubber mixes requires that manufacturing temperature be increased to $180^{\circ} \mathrm{C}[5-10]$, as the rubber lends a greater viscosity to the binder, thus making the bitumen more sensitive to decreases in temperature [11]. From a technical point of view, various solutions have been proposed in order to reduce manufacturing temperatures. One such solution is warm-mix asphalt, which allows for a reduction in manufacturing and installation temperatures by reducing the viscosity of the bitumen using organic and chemical additives or foaming processes [12-14].

If warm-mix technology is applied to rubberised bitumen, mixes with good properties could be produced at a lower cost and with less environmental impact. Although there are numerous studies of warm-mix bitumen, very few have considered bitumen and warm-mixes with tyre rubber [15-17].

This article presents the results of tests for dynamic viscosity, softening point, penetration, ductility at $25^{\circ} \mathrm{C}$ and elastic recovery on bitumen modified with $15 \%$ rubber and the corresponding control binders. $0 \%, 2 \%$ and $4 \%$ of four viscosity reducing additives were added to the mixtures. 


\section{Materials and test programme}

\subsection{Materials}

\subsubsection{Asphalt binder}

The net binder used in this study is a $\mathrm{B} 50 / 70\left(50 / 70 \times 10^{-1} \mathrm{~mm}\right.$ of penetration $)$, an asphalt bitumen which allows the manufacture and installation of asphalt mixes at normal temperatures. To this bitumen $15 \mathrm{wt} . \%$ of rubber was added in order to obtain a rubber-modified bitumen with increased viscosity. Table 1 indicates the basic specifications of these two binders; ' $\mathrm{B}$ ' refers to the $\mathrm{B} 50 / 70$ bitumen and ' $\mathrm{B}+15 \% \mathrm{R}$ ' to the B $50 / 70$ bitumen to which $15 \mathrm{wt} . \%$ of crumb rubber was added.

The asphalt bitumen was also subjected to a fractionation analysis as specified in the NLT 373/94 standard [18]. The results can be seen in Table 2.

\subsubsection{Crumb rubber modifier (CRM)}

The CRM used in this study was produced by mechanical shredding at ambient temperature by the Renecal company (Guardo, Spain). To ensure that the consistency of the CRM was maintained throughout the study, only one batch of crumb rubber was used. The gradation of the rubber used in this study is provided in Table

$50 \%$ of the rubber comes from lorry tyres and the remaining $50 \%$ from car tyres. A thermogravimetric analysis was completed on a TGA/SDTA 851 thermobalance and the results can be seen in Table 4 .

\subsubsection{Additives}

The organic additives used in this study are Sasobit ${ }^{\circledR}$, Asphaltan $A^{\circledast}$, Asphaltan $\mathrm{B}^{\oplus}$ and Licomont BS $100^{\oplus}$. Organic or wax additives are used to achieve temperature reductions by reducing the viscosity of the binder. Studies show that these waxes can reduce the viscosity of a bitumen, thereby allowing asphalt mixes to be manufactured at lower temperatures [13].

Sasobit ${ }^{\star 2}$ is a Fischer-Tropsch (F-T) wax which is produced by treating hot coal with steam in the presence of a catalyst. It is a long-chain aliphatic hydrocarbon wax with the melting range between $85^{\circ} \mathrm{C}$ and $115^{\circ} \mathrm{C}$, high viscosity at lower tem-

Table 1

Specifications of the B 50/70 bitumen without rubber and with $15 \mathrm{wt} . \%$ of rubber.

\begin{tabular}{llll}
\hline & Unit & B & B + 15\% R \\
\hline Penetration $\left(25^{\circ} \mathrm{C}\right)$ & $0.1 \mathrm{~mm}$ & 55.4 & 36.2 \\
Softening point & ${ }^{\circ} \mathrm{C}$ & 51.1 & 71.3 \\
\hline
\end{tabular}

Table 2

Fractionation analysis of the B 50/70 bitumen.

\begin{tabular}{ll}
\hline Fractionation analysis & B 50/70 \\
\hline Asphaltenes (\%) & 13.8 \\
Saturates (\%) & 9.7 \\
Naphthene-aromatic (\%) & 48.5 \\
Aromatic-polar (\%) & 28.0 \\
\hline
\end{tabular}

Table 3

Crumb rubber gradation.

\begin{tabular}{ll}
\hline Sieve $(\mathrm{mm})$ (UNE 933-2) & Accumulated (\%) \\
\hline 2.0 & 100.0 \\
1.5 & 100.0 \\
1.0 & 100.0 \\
0.50 & 94.1 \\
0.250 & 23.7 \\
0.125 & 3.7 \\
0.063 & 0.4 \\
\hline
\end{tabular}

Table 4

Thermogravimetic analysis of crumb rubber.

\begin{tabular}{lc}
\hline TGA & Rubber \\
\hline Plasticiser + additives (\%) & 4.67 \\
Polymer (rubber) (\%) & 57.41 \\
Carbon black (\%) & 32.22 \\
Ash (\%) & 6.02 \\
\hline
\end{tabular}

peratures and low viscosity at higher temperatures $[19,20]$. Asphaltan $A^{(}$is a Montan wax obtained by solvent extraction of certain types of lignite or brown coal; its effect on asphalt is similar to that of F-T waxes. Asphaltan $\mathrm{A}^{\otimes}$ melts at $125^{\circ} \mathrm{C}$ $[21,22]$. Asphaltan $B^{\circledR}$ is a refined Montan wax blended with a fatty acid amide. Its melting point is between 82 and $95^{\circ} \mathrm{C}$ [20]. Licomont BS $100^{\circ}$ is a fatty acid amide; these waxes are manufactured synthetically by reacting amines with fatty acids $[20,23]$. Licomont BS $100^{\circ}$ melts between $141^{\circ} \mathrm{C}$ and $146^{\circ} \mathrm{C}$ [13].

2.2. Production of rubberised warm asphalt binders

\subsubsection{Equipment}

The production equipment consisted of an oil bath with a maximum temperature of $225^{\circ} \mathrm{C}$, a mixer with a maximum velocity of $15,000 \mathrm{rpm}$ fitted with a propeller agitator and a one-litre metal container for mixing. The oil bath is equipped with a temperature probe that can be introduced into the mixing receptacle, allowing the temperature of the binder to be controlled with precision.

\subsubsection{Production protocol}

$750 \mathrm{~g}$ of each bitumen sample was prepared. First, the bitumen was heated to $140^{\circ} \mathrm{C}$. Then, the viscosity-reducing additive was introduced and the bitumen was mixed for $15 \mathrm{~min}$ at $4000 \mathrm{rpm}$, ensuring that the additive was properly integrated into the binder. Afterward, the mixture was heated to $190^{\circ} \mathrm{C}$ and the rubber added. Lastly, the mixture was blended for $30 \mathrm{~min}$ at $2000 \mathrm{rpm}$ and then for another $45 \mathrm{~min}$ at $1000 \mathrm{rpm}$, always at a temperature of $190^{\circ} \mathrm{C}$. Upon completion of this process, the bitumen was ready to be tested.

\section{Results and discussions}

\subsection{High-temperature viscosity}

Each rubberised warm-mix asphalt binder was tested using a Brookfield rotational viscometer. The viscosity was measured over the widest possible temperature range in order for the decrease in viscosity - caused by the incorporation of the additive - to be observed at different temperatures. The standard used in this test is UNE-EN 13302:2010 (Bitumen and bituminous binders - determination of dynamic viscosity of bituminous binder using a rotating spindle apparatus) [24]. The results of the tests are summarised in Figs. 1-9.

As can be observed in Fig. 1, the addition of $15 \%$ crumb rubber to the B 50/70 bitumen increases the viscosity and, consequently, the manufacturing and compaction temperatures are increased. This is one of the major drawbacks of rubber-modified bitumen.

Fig. 2 exhibits the influence of the Sasobit ${ }^{(2)}$ additive on the dynamic viscosity of a bitumen without rubber.

F-T waxes such as Sasobit ${ }^{(6)}$ have fusion points between 85 and $115^{\circ} \mathrm{C}$ [13]. It can be seen that beyond $100^{\circ} \mathrm{C}$ a change occurs due to the fact that, as the Sasobit ${ }^{\text {(B) }}$ melts, the viscosity decreases. In the end, the $4 \%$ Sasobit ${ }^{*}$ curve remains below the $2 \%$ curve.

The introduction of the Asphaltan $\mathrm{A}^{(2)}$ additive (Fig. 3 ) produced a decrease in viscosity. It can be observed that the change was produced between 110 and $115^{\circ} \mathrm{C}$, as the fusion point of this additive is at $125^{\circ} \mathrm{C}[21,22]$. The $4 \%$ viscosity curve remains slightly below the $2 \%$ curve.

With the Asphaltan $\mathrm{B}^{\circledR}$ (Fig. 4), the change in viscosity was produced between 90 and $100^{\circ} \mathrm{C}$, as this type of wax has a lower fusion point than $\mathrm{F}-\mathrm{T}$ waxes [13]. It can be observed that the $4 \%$ viscosity curve remains below that of the $2 \%$ mixture.

The effect of the Licomont BS $100^{\otimes}$ (Fig. 5) on the viscosity of the bitumen is the same as that described in the previous cases, save that the decrease occurred at a higher temperature - above $120^{\circ} \mathrm{C}$ - as this type of wax has a higher fusion point $[20,23]$.

Figs. 6-9 show the influence of the additives on bitumen with $15 \%$ rubber. It can be seen that, with all of the additives, the viscosity of the bitumen with rubber decreases in proportion to the additive content, indicating that each one has the potential to reduce the mixing and compaction temperatures of asphalt rubber hot mixes.

The viscosity of the rubberised bitumen containing Sasobit ${ }^{\circledR}$ (Fig. 6) decreases in proportion to the quantity of the additive. The viscosity is lowest when the Sasobit ${ }^{\circledR}$ content is $4 \%$. 


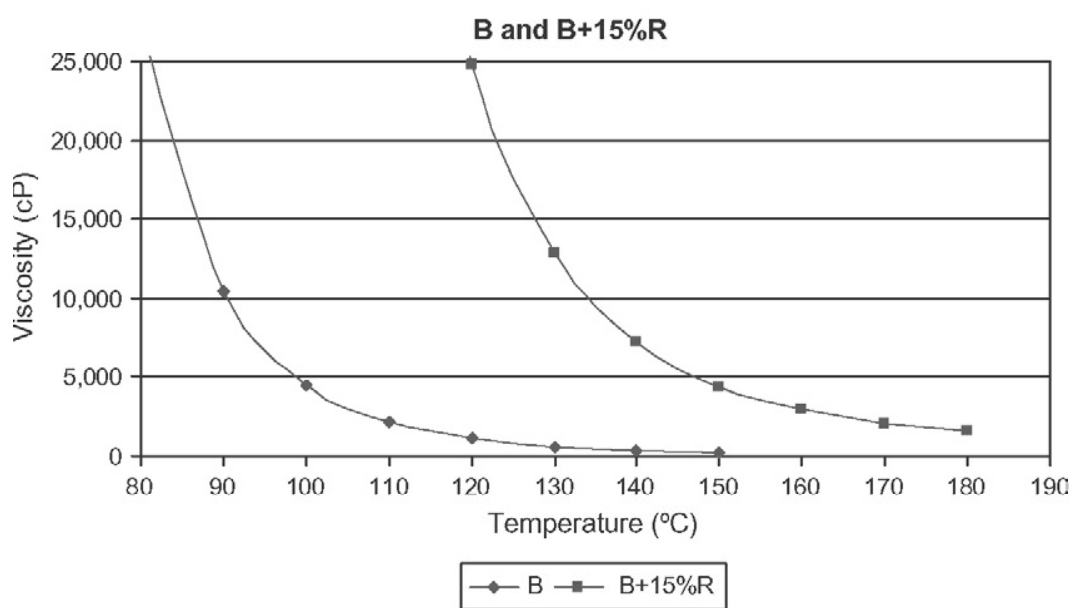

Fig. 1. Effect of rubber on dynamic viscosity.

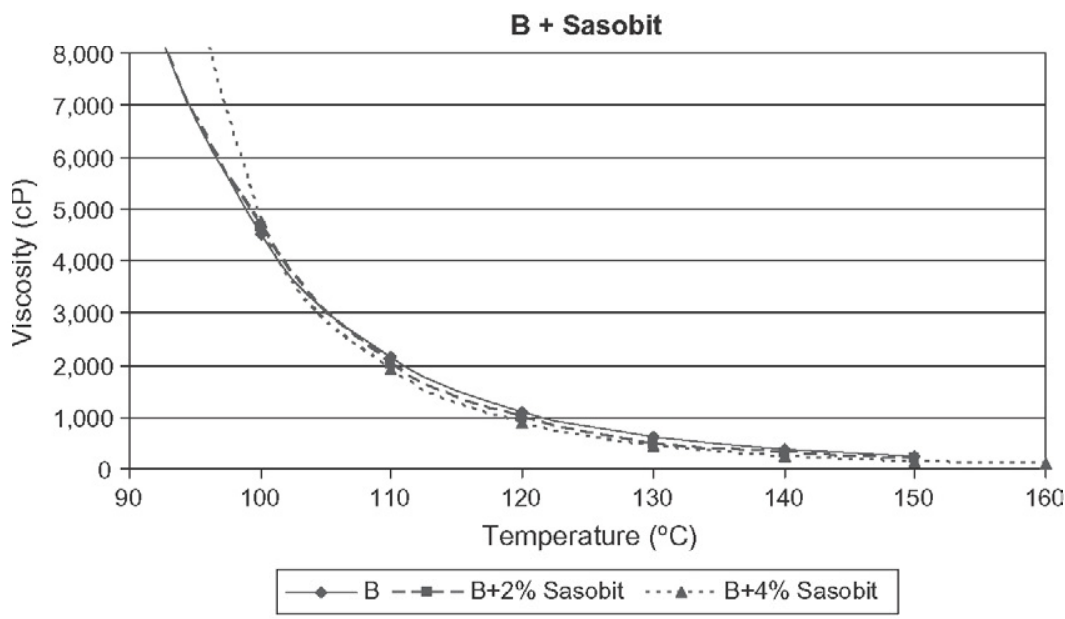

Fig. 2. Influence of Sasobit ${ }^{\circledast}$ on dynamic viscosity of B 50/70.

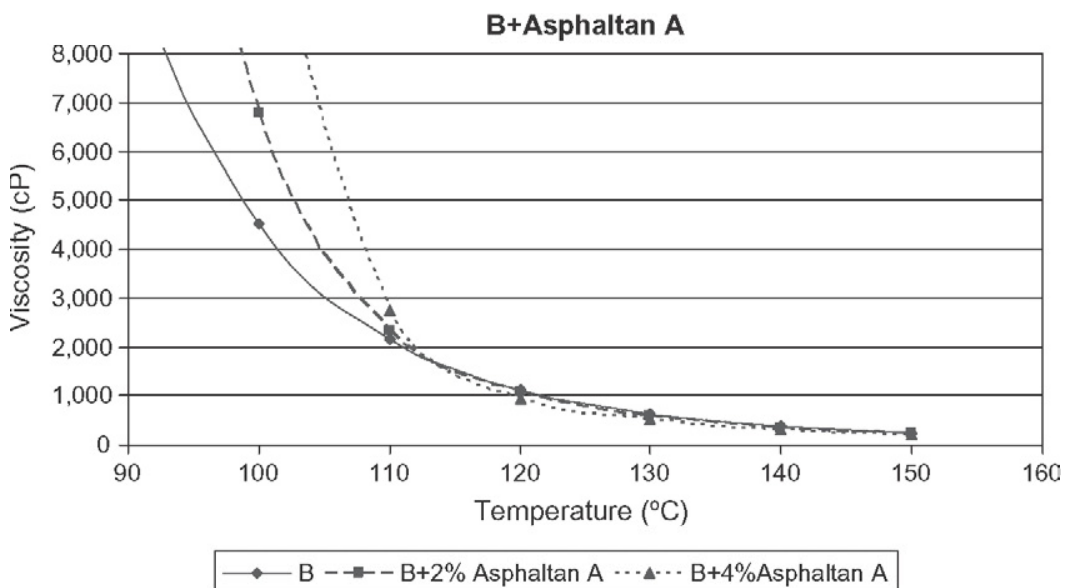

Fig. 3. Influence of Asphaltan $A^{\circledR}$ on dynamic viscosity of B 50/70.

In the case of Asphaltan $A^{\circledR}$ (Fig. 7), the viscosity decreases considerably, even more so when $4 \%$ of this wax is added.

In the same way, a decrease in viscosity of the bitumen can be observed with the addition of the Asphaltan $\mathrm{B}^{\circledR}$ (Fig. 8); the viscosity is lowest with $4 \%$ of this additive.

The Licomont BS $100^{\circledR}$ additive (Fig. 9) also considerably reduces viscosity when $4 \%$ of this additive is incorporated into the bitumen; the addition of $2 \%$ produces a much less pronounced effect.

By incorporating the additives into a B 50/70 bitumen and a B $50 / 70$ bitumen with $15 \%$ rubber, a viscosity reduction occurs which can lead to a reduction in the manufacturing temperatures of bituminous mixtures. In order to estimate how much the temperature could theoretically be lowered using these additives, several calcu- 


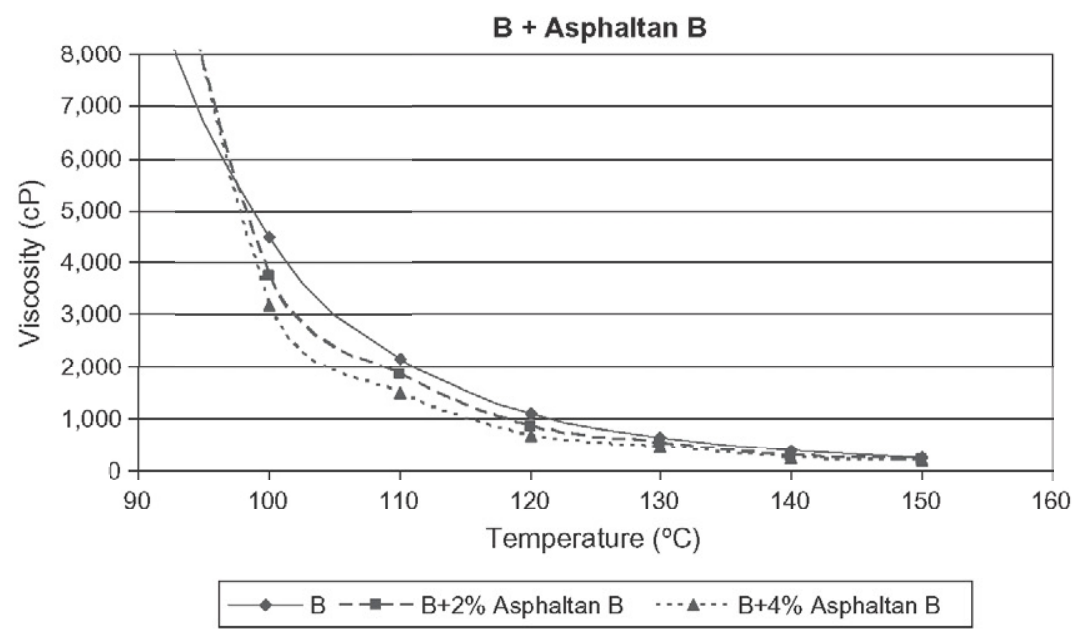

Fig. 4. Influence of Asphaltan $B^{\circledast}$ on dynamic viscosity of B 50/70.

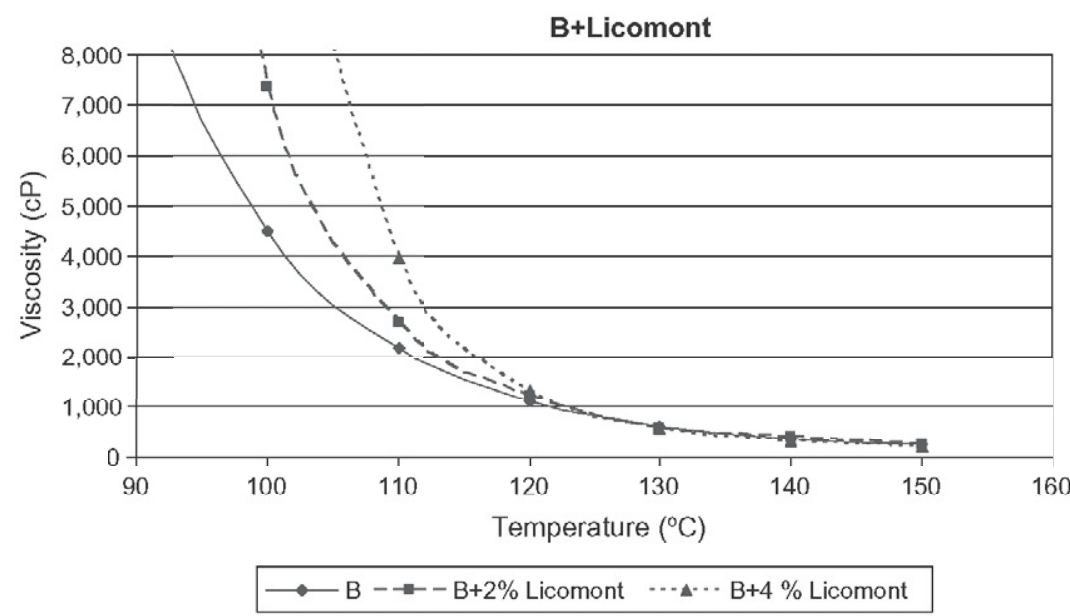

Fig. 5. Influence of Licomont BS $100^{\Phi}$ on dynamic viscosity of B 50/70.

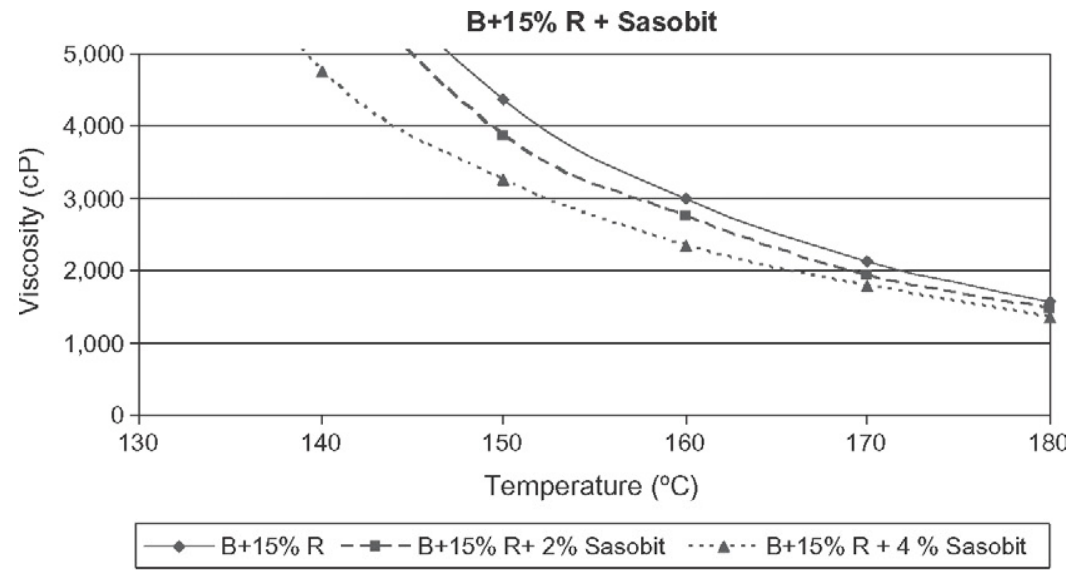

Fig. 6. Influence of Sasobit ${ }^{80}$ on dynamic viscosity of bitumen modified with $15 \%$ rubber.

lations have been made, taking as a reference the fact that the ideal mixture of B 50/70 and aggregates for the manufacture of bituminous mixtures is produced when the viscosity of the bitumen is close to $180 \mathrm{cP}$ (mPa s), which is reached at a temperature of some $170^{\circ} \mathrm{C}$. For a B $50 / 70$ bitumen with $15 \%$ rubber, the ideal viscosity is around $1500 \mathrm{cP}(\mathrm{mPa} \mathrm{s})$, attainable at around $180^{\circ} \mathrm{C}$. A summary of these calculations can be found in Figs. 10 and 11. In both cases, the addition of $4 \%$ of each additive causes a greater decrease in the manufacturing temperature of the bituminous mixtures than that produced by adding only $2 \%$. 


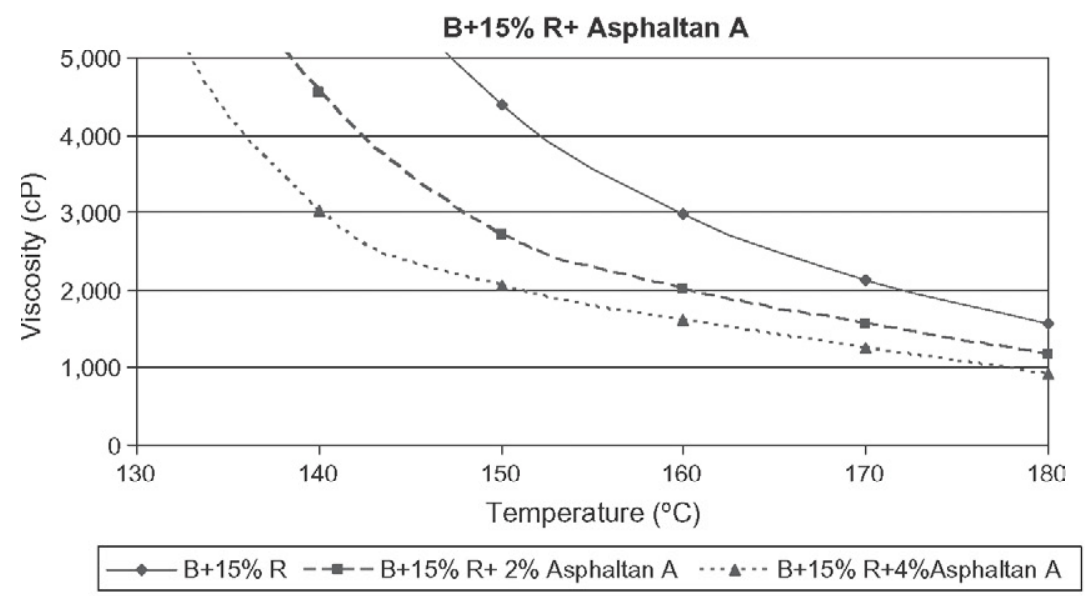

Fig. 7. Influence of Asphaltan $A^{\circledR}$ on dynamic viscosity of bitumen modified with $15 \%$ rubber.

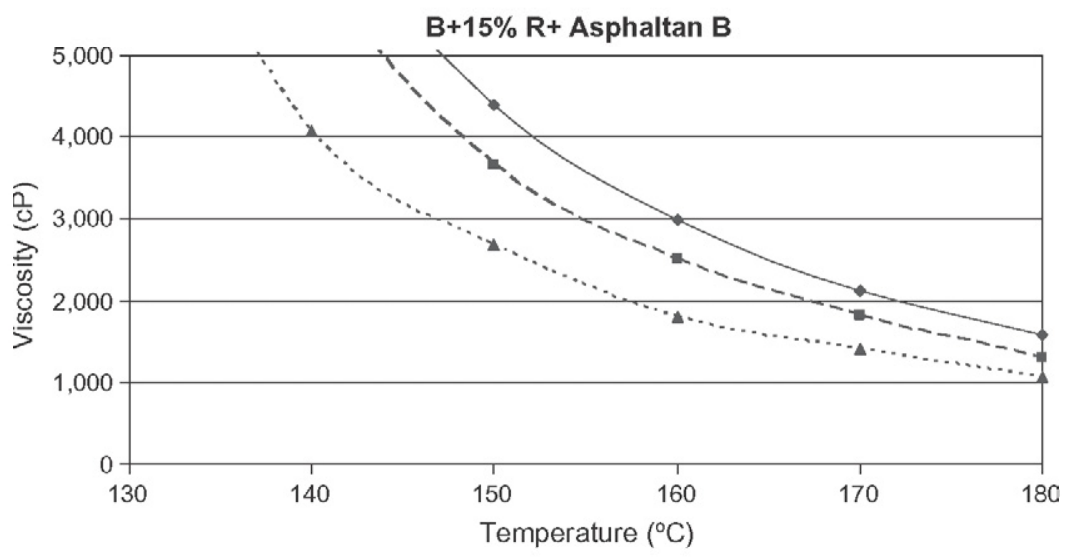

$\rightarrow-B+15 \% R \quad--B+15 \% R+2 \%$ Asphaltan B $\cdots \cdots \cdot B+15 \% R+4 \%$ Asphaltan $B$

Fig. 8. Influence of Asphaltan $B^{\circledR}$ on dynamic viscosity of bitumen modified with $15 \%$ rubber.

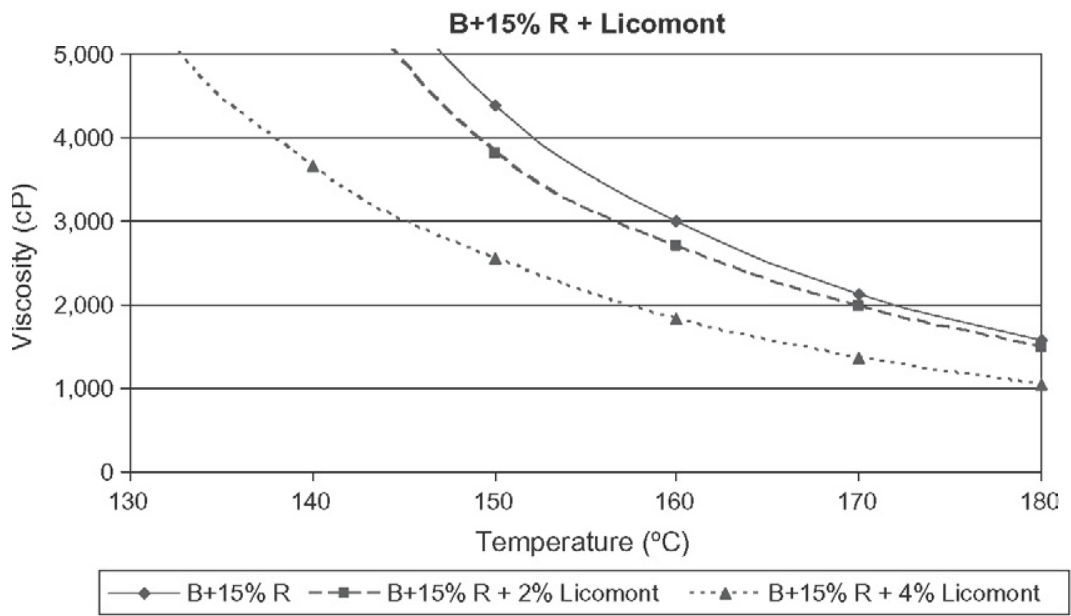

Fig. 9. Influence of Licomont BS $100^{\circ}$ on dynamic viscosity of bitumen modified with $15 \%$ rubber.

In the case of a bitumen without rubber, the additive which most successfully reduces the manufacturing temperature is the $4 \%$ Sasobit ${ }^{*}$, which reduces the temperature by $25^{\circ} \mathrm{C}$, followed by the $4 \%$ Asphaltan $A^{(*)}$.
For B 50/70 bitumen with 15\% rubber, the additive which produces the greatest reduction in manufacturing temperature is the $4 \%$ Asphaltan $A^{(i)}$, reducing the temperature by some $18^{\circ} \mathrm{C}$, followed by the $4 \%$ Licomont $^{(2)}$ and the $4 \%$ Asphaltan $B{ }^{\circledR}$. 


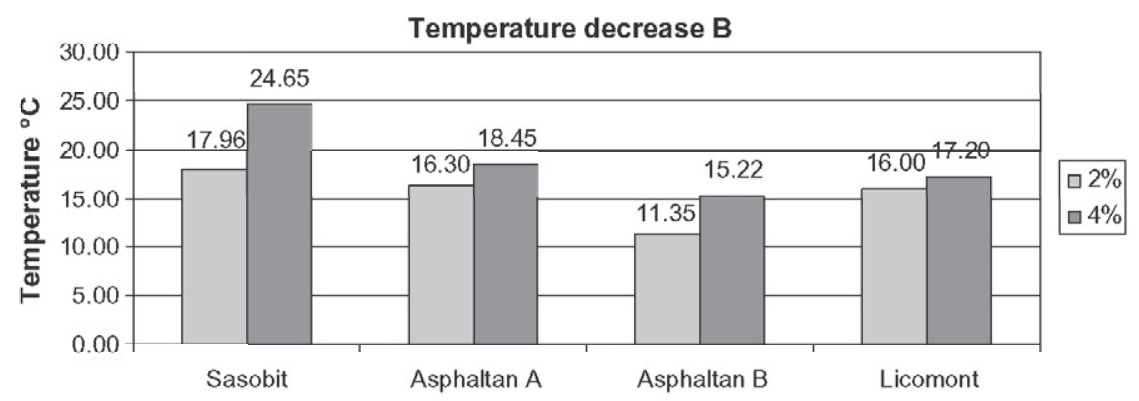

Fig. 10. Temperature decrease of B $50 / 70$.

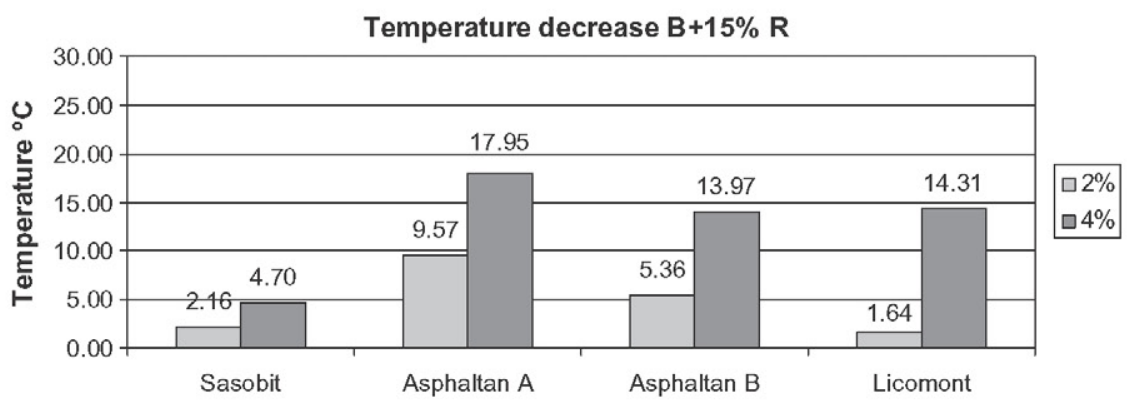

Fig. 11. Temperature decrease of bitumen modified with $15 \%$ rubber.

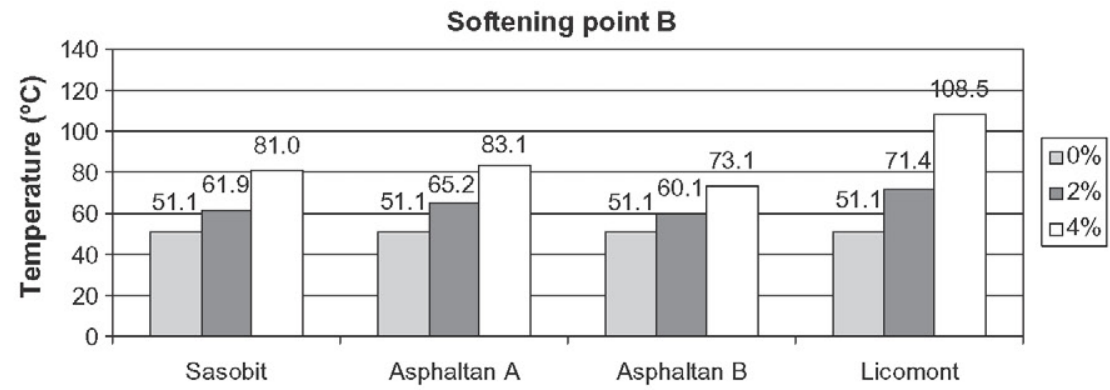

Fig. 12. Influence of additives on softening point of B 50/70.

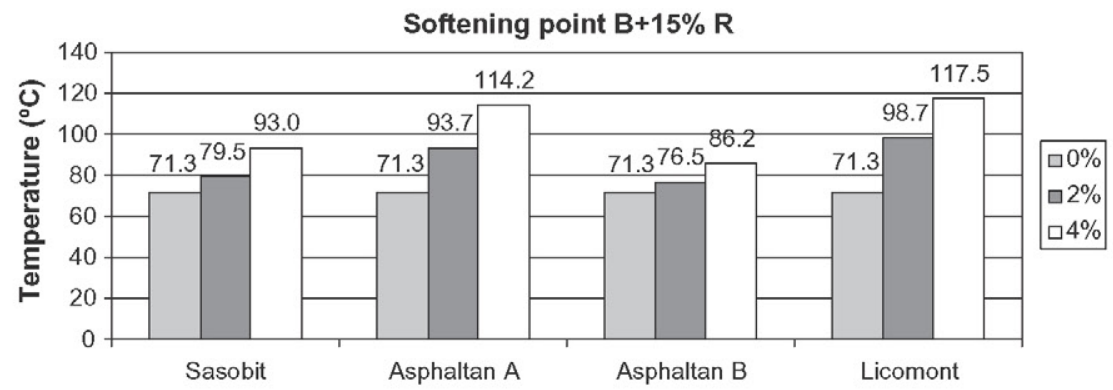

Fig. 13. Influence of additives on softening point of bitumen modified with $15 \%$ rubber.

\subsection{Softening point}

The softening point test establishes the temperature at which the bitumen softens. The standard used for this test is UNE-EN 1427:2007 (Bitumen and bituminous binders - determination of the softening point - ring and ball method) [25]. The results of the ring and ball test are summarised in Figs. 12 and 13.

It can be observed in Figs. 12 and 13 that the softening points increase due to the presence of the rubber on the one hand, and, on the other, to the incorporation of the organic additives. Thus, the rubber and each of the additives studied here act as stabilisers, improving the resistance of the bituminous mixtures to plastic deformation.

This increase in the softening temperature is in keeping with the fact that the waxes used in this study have fusion temperatures greater than $90^{\circ} \mathrm{C}$, meaning that at lower temperatures not only do they not fluidify the binder, but instead help to stiffen it. The additive which demonstrated the highest softening point is the Lico- 


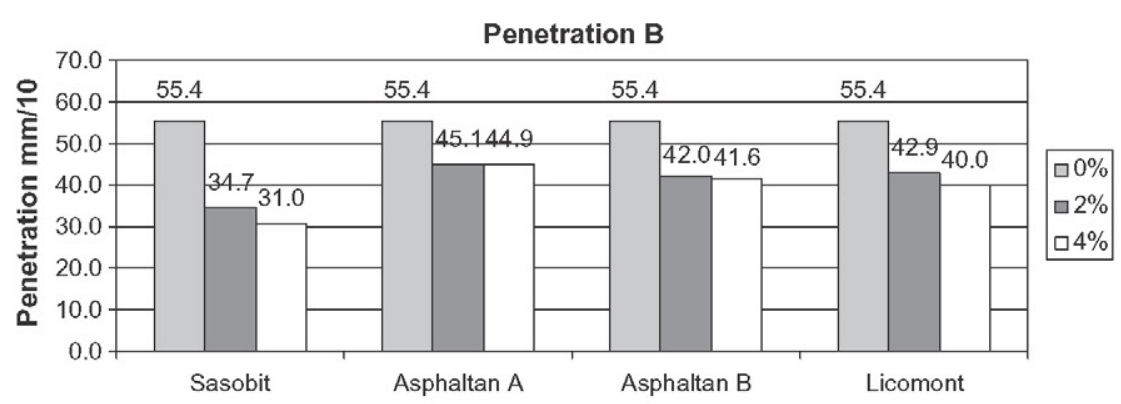

Fig. 14. Influence of additives on penetration of B 50/70.

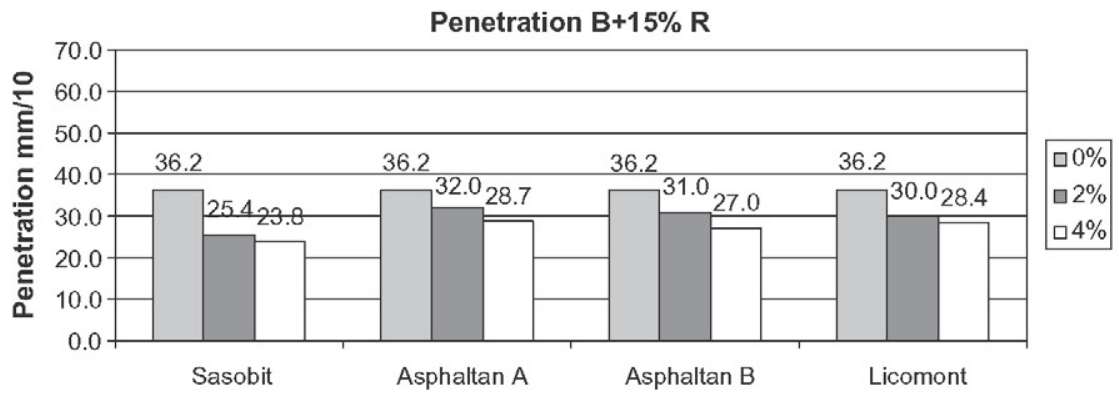

Fig. 15. Influence of additives on penetration of bitumen modified with $15 \%$ rubber.

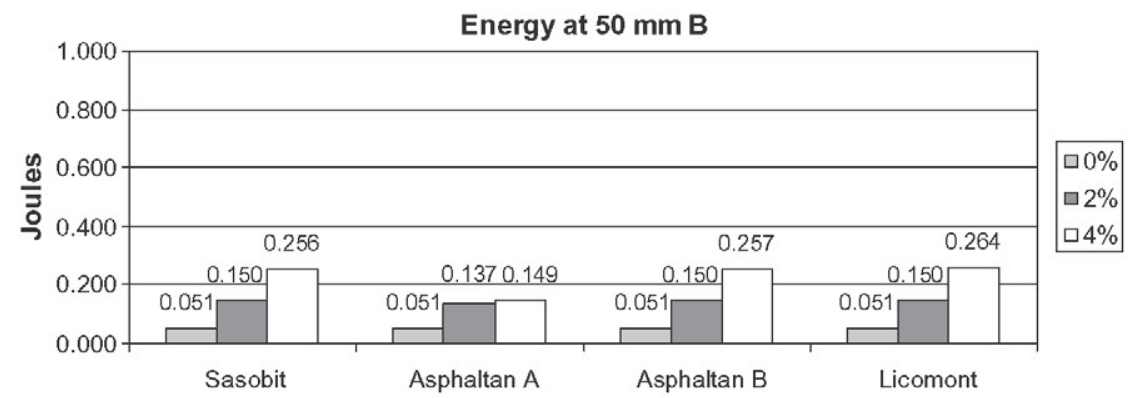

Fig. 16. Influence of additives on ductility of B 50/70.

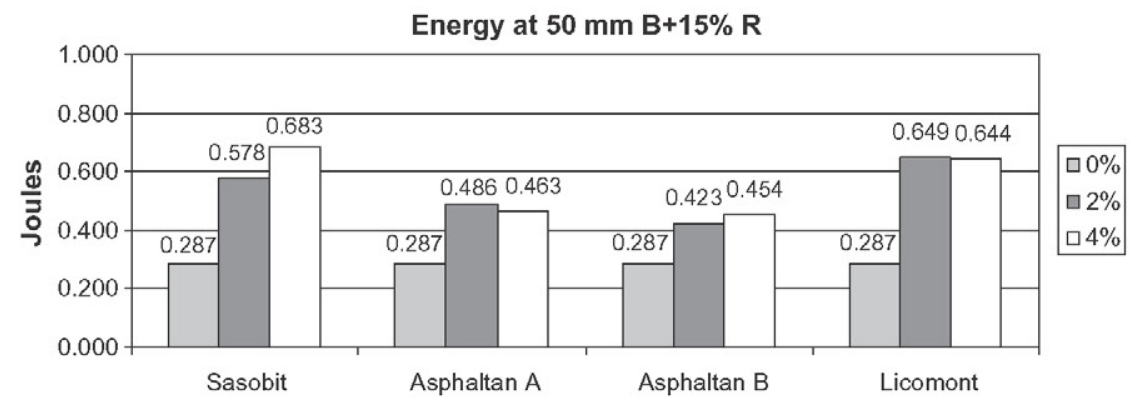

Fig. 17. Influence of additives on ductility of bitumen modified with $15 \%$ rubber.

mont BS $100^{\circledR}$, followed by the Asphaltan $A^{\circledR}$, Asphaltan $B^{\circledR}$ and Sasobit ${ }^{\circledR 2}$.

\subsection{Needle penetration}

The penetration test establishes the consistency of the bitumen at $25^{\circ} \mathrm{C}$ by means of an indentation test. The test was based on the
UNE-EN 1426 standard (Bitumen and bituminous binders - determination of needle penetration) [26] and the results can be seen in Figs. 14 and 15.

In Figs. 14 and 15, one can observe that the incorporation of rubber reduces penetration, as rubber increases the stiffness of the binder. Furthermore, the incorporation of the additives also reduces penetration. This is due to the fact that viscosity-reducing 


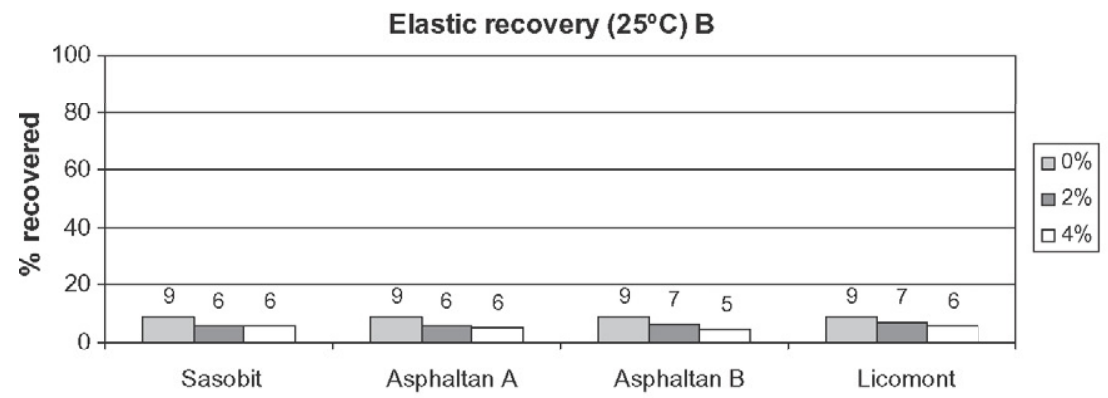

Fig. 18. Influence of additives on elastic recovery of B 50/70.

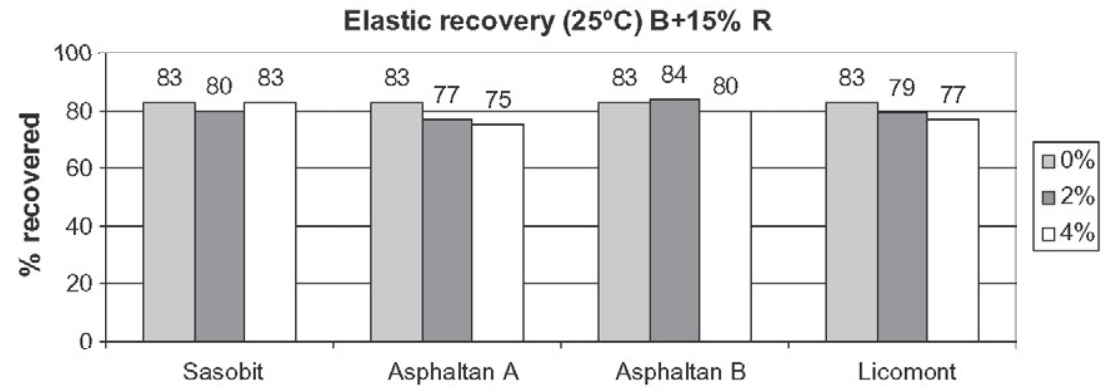

Fig. 19. Influence of additives on elastic recovery of bitumen modified with $15 \%$ rubber.

additives do not fluidify until fusion, which occurs at temperatures greater than $90^{\circ} \mathrm{C}$, and the penetration test is performed at $25^{\circ} \mathrm{C}$, a temperature at which the additives increase the stiffness of the binder. When comparing the different additives, the bitumen containing the Sasobit ${ }^{\circledR}$ additive was the stiffest; the softest was the bitumen with Asphaltan $A^{\circledast}$.

\subsection{Ductility}

The force-displacement curve of a binder is obtained using a classic ductility testing machine with a load cell and a displacement transducer. The standard used in this study was UNEEN13589:2008 (determination of the tensile properties of modified bitumen by the force ductility method) [27]. According to this standard, the test sample must be stretched in a ductilometer at a specific test temperature and at a consistent speed until it breaks or until it reaches $1.333 \%$ elongation $(400 \mathrm{~mm})$.

The force-ductility test values are expressed as the difference between the conventional energy measured at specific elongation points $(0.2 \mathrm{~m}$ and $0.4 \mathrm{~m})$. In the case of asphalt rubber, the bitumen breaks before reaching these lengths. Thus, in order to compare the results in a homogenous manner, the conventional energy was measured at $50 \mathrm{~mm}$. The results are shown in Figs. 16 and 17.

Despite using $50 \mathrm{~mm}$ as the maximum length, the heterogeneity of the rubber particles produced a significant dispersion among the results, which do not display a clear tendency; for this reason, the test cannot be considered reliable. During the tests, it was observed that the binder did not flow homogenously to form a thin thread, but that instead the rubber particles caused the binder to break prematurely. The results of this test are not as clear as those of the viscosity, softening point and penetration tests, which are not as affected by the heterogeneity caused by the rubber particles in suspension in the binder. Despite this, it seems that the incorporation of the rubber increases the breaking energy, as the binder is stiffer at the testing temperature of $25^{\circ} \mathrm{C}$. The different additives, however, do not seem to have a clear influence on ductility.

Thus, it can be confirmed that the ductility test is not suitable for rubberised binders. This could lead to a new line of research to determine a reliable way of measuring the cohesion of rubbermodified bitumen.

\subsection{Elastic recovery}

The UNE 13398 standard (bitumen and bituminous binders determination of the elastic recovery of modified bitumen) [28] was applied for this test. In Figs. 18 and 19, the results of the elastic recovery test can be seen. The aforementioned standard stipulates that readings be taken at $200 \mathrm{~mm}$; however, due to the fact that rubber-modified binders break before reaching this length, the readings were taken at $100 \mathrm{~mm}$ instead.

One can observe that the addition of rubber improves the elastic recovery of the bitumen, while the different additives do not seem to have a distinguishable effect.

\section{Conclusions}

This study has shown that the incorporation of the four organic additives (Sasobit ${ }^{\circledR}$, Asphaltan $A^{\circledR}$, Asphaltan $B^{\left({ }^{\circledR}\right.}$ and Licomont BS $100^{\circledR}$ ) reduces the viscosity of a binder modified with $15 \%$ rubber. The additive which produced the greatest reduction in the manufacturing temperature is the $4 \%$ Asphaltan $\mathrm{A}^{\circledR}$, followed by Asphal$\tan B^{(\infty)}$ and Licomont ${ }^{\circledR}$. However, in the bitumen without rubber, the most effective additive is the $4 \%$ Sasobit ${ }^{\circledR}$.

It was observed that, in general, the theoretical reduction of the manufacturing temperature of bituminous mixtures is smaller in bitumen with $15 \%$ rubber than in pure binders. It was also demonstrated that the addition of $4 \%$ of any one of the additives produces a greater decrease in viscosity than when merely $2 \%$ of the additive was used.

In the same way, the incorporation of these additives into the binder modified with $15 \%$ rubber causes the penetration to decrease; this is due to fact that the softening temperature increases and is in keeping with the fact that the fusion temperatures of the waxes are higher than the temperature at which the penetration and softening point tests were conducted. The additive which most 
increased the softening temperature is the $4 \%$ Licomont BS $100^{\circledR}$ followed by the $4 \%$ Asphaltan $A^{\circledR}$. The additive which best reduced penetration is the $4 \%$ Sasobit ${ }^{\mathbb{Q}}$. It was observed that the higher the additive content, the higher the softening point and the lower the results of the penetration test. This is significant because the penetration and softening point are two of the properties required for the technical specifications of binders; thus, in order to design a bitumen with rubber for warm-mixes, one must consider not only the viscosity reduction achieved by the additive, but also the important changes which it can cause to other properties. In short, the rubber and additive content must be considered together in order for the final product to fall within the legal specifications and so that the other properties of the binder are not compromised, leading, for example, to excessive rigidity due to the lack of penetration of the binder.

The incorporation of the rubber notably increases the percentage of elastic recovery of the bitumen, but it was not possible to clearly establish the effect of the organic additives, as it appeared to be insignificant in all cases.

Lastly, the ductility test at $25^{\circ} \mathrm{C}$ does not seem to be reliable, as the heterogeneity caused by the rubber particles in suspension in the binder produces premature breakage, preventing the test from proceeding normally. For this reason, it would be advisable to open a new line of research to determine a reliable way of measuring the cohesion of rubber-modified bitumen.

\section{Acknowledgements}

This study was supported by the Escuela Técnica Superior de Ingenieros de Caminos, Canales y Puertos (E.T.S.I.C.C.P.) of the Department of Civil Engineering: Transport of the Technical University of Madrid (UPM). The authors would like also to thank Repsol, Renecal, Iberceras, Romonta and Clariant for supplying the binders, rubber and wax additives.

\section{References}

[1] Huang B, Mohammad LN, Graves PS, Abadie C. Louisiana experience with crumb rubber-modified hot-mix asphalt pavement. Transp Res Rec J Transp Res Board 2002:1789:1-13.

[2] Liang RY, Lee S. Short-term and long-term aging behavior of rubber modified asphalt paving mixtures. Transp Res Rec J Transp Res Board 1996;1530:11-7.

[3] Ruth BE, Roque R. Crumb rubber modifier (CRM) in asphalt pavements. Proc Transp Congr 1995:768-85.

[4] Shen J, Amirkhanian S, Lee S-J. Effects of rejuvenating agents on recycled aged rubber modified binders. Int J Pavement Eng 2005;6(4):273-9.

[5] Akisetty CK, Lee S-J, Amirkhanian SN. Effects of compaction temperature on volumetric properties of rubberized mixes containing warm-mix additives. J Mater Civ Eng 2009·21(8):409-15.

[6] Akisetty CK, Lee S-J, Amirkhanian SN. Laboratory investigation of the influence of warm asphalt additives on long-term performance properties of CRM binders. Int J Pavement Eng 2010;11(2):153-60.

[7] Akisetty CK, Lee SJ, Rogers W, Amirkhanian SN. Evaluation of engineering properties of rubberized laboratory mixes containing warm mix additives. J Test Eval 2010;38(1).
[8] Gandhi T, Akisetty C, Amirkhanian S. A comparison of warm asphalt binder aging with laboratory aging procedures. J Test Eval 2010;38(1).

[9] Akisetty C, Xiao F, Gandhi T, Amirkhanian S. Estimating correlations between rheological and engineering properties of rubberized asphalt concrete mixtures containing warm mix asphalt additive. Constr Build Mater $2011 ; 25(2): 950-6$

[10] Akisetty CK, Gandhi T, Lee S-J, Amirkhanian SN. Analysis of rheological properties of rubberized binders containing warm asphalt additives. Can J Civ Eng 2010;37(5):763-71.

[11] CEDEX (Centro de Estudios y Experimentación de Obras Públicas). Manual de Empleo de Caucho de NFU en Mezclas Bituminosas. Ministerio de Fomento, Ministerio de Medio Ambiente: 2007.

[12] Hurley G, Prowell B. Evaluation of Sasobit ${ }^{\circledR}$ for use in warm mix asphalt. NCAT Report; 2005.

[13] D́Angelo J et al. Warm-Mix asphalt: european practice. Report No. FHWA-PL08-007. Alexandria (USA): American Trade Initiatives; 2008

[14] Rubio MC, Martínez G, Baena L, Moreno F. Warm mix asphalt: an overview. J. Clean Prod 2012;24:76-84. 3.

[15] Akisetty CK, Lee SJ, Amirkhanian SN. High temperature properties of rubberized binders containing warm asphalt additives. Constr Build Mater 2009:23:565-73. 1 .

[16] Wang H, Dang Z, You Z, Cao D. Effect of warm mixture asphalt (WMA) additives on high failure temperature properties for crumb rubber modified (CRM) binders. Constr. Build. Mater. 2012;35:281-8. 10.

[17] Xiao F, WenbinZhao PE, Amirkhanian SN. Fatigue behavior of rubberized asphalt concrete mixtures containing warm asphalt additives. Constr Build Mater 2009;23:3144-51. 10.

[18] Centro de Estudios de Carreteras (Madrid) and Centro de Estudios y Experimentaciôn de Obras Públicas., Normas NLT. I, Ensayos De Carreteras. NLT 373/94, Fraccionamiento De Los Betunes asfálticos; 1999.

[19] Nölting M. 10 years of Sasobit technology experiences, applications and outlook. BASt, Germany, Presentation to WM A Scan Team; 2007.

[20] Hirsch V. Warm Mix Asphalt Technologies. BASt. Presentation to WM A Scan Team. Germany; 2007.

[21] Drüschner L. Experience with Warm Mix Asphalt in Germany. Sønderborg NVF-rapporter. Guest Report in Conference; 2009.

[22] Damm K, Abraham J, Butz T, Hildebrand G, Riebeschl G. Asphalt flow improvers as 'Intelligent Fillers' for hot asphalts - a new chapter in asphalt technology. J Appl Asphalt Binder Technol 2002:36-69.

[23] Wölfe $\mathrm{H}$, Orlamünder $\mathrm{K}$. Bitumen modification with additives for road construction - technology of low-temperature Asphalt. BASt. Presentation to WM A Scan Team. Germany; 2007.

[24] AENOR, Asociación Española de Normalización y Certificación. UNE-EN 13302:2010. Bitumen and bituminous binders - determination of dynamic viscosity of bituminous binder using a rotating spindle apparatus. Serie Construcciôn, Áridos para mezclas bituminosas y tratamientos superficiales de carreteras Madrid. Spain; 2010

[25] AFNOR Asociación Fspañola de Normalización y Certificación UNE-FN 1427:2007. Bitumen and bituminous binders - determination of the softening point - ring and Ball method. Serie Construcciôn, Âridos para mezclas bituminosas y tratamientos superficiales de carreteras Madrid. Spain 2007.

[26] AENOR Asociación AENOR Asociación Española de Normalización y Certificación. UNE-EN 1426:2003. Bitumen and bituminous binders determination of needle penetration. Serie Construcción, Âridos para mezclas bituminosas y tratamientos superficiales de carreteras Madrid. Spain; 2003.

[27] AENOR, Asociaciôn Española de Normalizaciôn y Certificación. UNEEN13589:2008. Bitumen and bituminous binders-Determination of the tensile properties of modified bitumen by the force ductility method. Serie Construcción, Áridos para mezclas bituminosas y tratamientos superficiales de carreteras Madrid. Spain; 2008.

[28] AENOR, Asociación Española de Normalización y Certificación. UNE-EN 13398:2010 Bitumen and bituminous binders - determination of the elastic recovery of modified bitumen. Serie Construcción, Aridos para mezclas bituminosas y tratamientos superficiales de carreteras Madrid. Spain; 2010. 